\title{
Pathology of Peripheral Lymph Node Biopsies in Kano, Northern Nigeria
}

\author{
${ }^{1}$ O. Ochicha, ${ }^{2}$ S.T. Edino, ${ }^{1}$ A. Z. Mohammed, ${ }^{1}$ A. B. Umar and ${ }^{1}$ A. T. Atanda \\ Departments of ${ }^{1}$ Pathology and ${ }^{2}$ Surgery, Bayero University and Aminu Kano Teaching Hospital, \\ Kano, Nigeria \\ Reprint requests to: Dr. O. Ochicha, Pathology Department, Aminu Kano Teaching Hospital, \\ P. M. B. 3452 Kano, Nigeria.E-mail: ochicha@googlemail.com
}

\begin{abstract}
Background: Lymphadenopathy is a common clinical problem here in Kano, Northern Nigeria but there has been no formal study. We therefore undertook this review to evaluate the pattern in our locality.

Method: This is a seven-year (1998-2004) retrospective review of all histologically diagnosed lymph node biopsies received at Aminu Kano Teaching Hospital, Kano.

Results: Cervical, axillary and inguinal nodes were the most frequently biopsied accounting for $46 \%$, $23 \%$ and $13 \%$, while tuberculosis, lymphomas and metastases were the most commonly diagnosed lesions comprising $30 \%, 24 \%$ and $19 \%$ respectively. In general, benign lesions were more common constituting $57 \%$ of nodal biopsies. Lymphadenopathy was observed to be most prevalent in the first three decades.

Conclusion: Our findings were broadly similar to most other Nigerian studies and slightly at variance with other African countries but significantly different from the Western World. The limitations of lymph node histopathology in the absence of modern molecular diagnostic techniques are highlighted.
\end{abstract}

Key words: Lymphadenopathy, tuberculosis, lymph node metastases, reactive hyperplasia

\begin{abstract}
Résumé
Introduction: La lymphadenopathie est un probléme clinique courant ici à Kano, Nord du Nigeria, cependant il n'ya encore eu aucune étude formelle sur ce sujet. C'est pour cette raison que nous avons décidé d'entreprendre cette étude pour evaluer la distribution dans notre localité.

Méthodes: Voici une etude retrospective faite en sept ans (1998-2004) de tous les diagnostique histologique des ganglions lymphatiques reçus á Aminu Kano Teaching Hospital Kano.

Resultats: Les echantillons des ganglions cervicaux, axillaires et inguinaux etaient les plus fréquents, avec une frequence de $46 \%, 23 \%$ et $13 \%$ respectivement. Par ailleurs la tuberculose, les lymphomes et les metastases etaient les lesions les plus diagnostiquées avec les pourcentages de $30 \%, 24 \%$ et $19 \%$ respectivement.

En general, les lesions benignes etaient les plus observées avec un pourcentage de 53\%. La lymphadenopathie etait plus frequente pendant les trois premiere decenies.

Conclusion: Nos resultats etaient identiques à ceux obtenus au cours des études faites dans les autres localités du Nigeria juste avec les petites differences. Ceci s'applique aussi dans le autres pays Africains, mais il ya une trés grande difference avec les pays Occidentaux. En l'absence des techniques de diagnostique moleculaire morderne, les limitations de l'histopathologie des ganglions lymphatiques ont été mentionées.
\end{abstract}

Mots clés: Lymphadenopathie, tuberculosis, metastases, les ganglion lymphatiques, hyperplasie reactive

\section{Introduction}

Lymphadenopathy is a common clinical problem, and biopsies are usually undertaken to determine the cause of nodal enlargement, which may be neoplastic or non-neoplastic. The neoplastic disorders are mainly lympho-haematogenous malignancies and metastases while the non-neoplastic causes are more varied infections, drug reactions (including certain vaccines), lipid storage disorders and a wide variety of miscellaneous non-neoplastic lymphoproliferative disorders such as Castleman and Rosai Dorfman diseases. ${ }^{1}$

Published reports from within and outside Nigeria document a preponderance of non-neoplastic lesions with non-specific reactive hyperplasia predominating in the developed world, and tuberculosis the leading cause in Africa particularly with the current 
HIV/AIDS pandemic. ${ }^{2-9}$ HIV not only directly causes lymphadenopathy but is also an indirect cause via several AIDS-defining illnesses. ${ }^{10}$

Clinically, lymphadenopathy may be peripheral or visceral. Peripheral lymphadenopathies are easily detected by routine physical examination and are often biopsied as they are easily accessible for lymphadenectomy, which is a minor surgical procedure. Visceral lymphadenopathy on the other hand, requires laparatomy or sophisticated imaging techniques for detection.

Among the peripheral nodes, those in the upper part of the body (cervical, supraclavicular, axillary) are preferentially biopsied than lower limb nodes (popliteal, inguinal or femoral) as the former are more likely to yield definitive diagnosis whereas the latter are often characterized by non-specific reactive or chronic inflammatory and fibrotic changes. ${ }^{1,3}$

\section{Materials and Methods}

This is a retrospective study of histologically diagnosed lymph node biopsies at the histopathology laboratory of Aminu Kano Teaching hospital, Kano, Nigeria from $1998-2004$. This is the referral centre offering histopathology services to Kano and neighbouring states of Jigawa, Kastina and Bauchi.

Histology slides of all cases were reviewed and clinical data (age, sex, site) obtained from histology request forms and register. All slides were made from paraffin embedded blocks, then routinely stained with haematoxylin and eosin. Special stains like ZiehlNeelson were employed where necessary. Immunohistochemistry, cytogenetics and molecular diagnostic techniques like lymphocyte receptor gene rearrangements were not employed as these are not available in our laboratory. Consequently, our classification of non-Hodgkin lymphomas was based on the working formulation. ${ }^{11}$

\section{Results}

Three hundred and fifty six peripheral node biopsies were received during the period under review, accounting for $5 \%$ of all surgical biopsy specimens.
Two hundred and three of these were from males and 153 from females $(\mathrm{M}: \mathrm{F}=1.3: 1)$.

Table 1 presents the histological diagnoses and age distribution of lymph node biopsies in Kano. Lymphadenopathies mostly occurred in the first three decades of life, with a gradual decline in prevalence after the 3 rd decade.

Benign lesions were more common comprising $57 \%$ (249 cases), and tuberculosis (TB) was by far the most frequent cause accounting for $29.5 \%$ (105 cases) of peripheral lymphadenopathy in this series. TB was most prevalent in children and young adults with $80 \%$ of cases in the first three decades of life. Reactive hyperplasia (mostly follicular and paracortical) were the second commonest non-neoplastic lesion occurring in $19 \%$ of nodal biopsies in Kano.

Malignancies comprised $43 \%$ of enlarged peripheral lymph nodes, with lymphomas predominating accounting for $24 \%$, making them collectively the second most prevalent cause of lymphadenopathy in this series. Among the lymphomas, non-Hodgkin lymphomas (NHLs) were more common accounting for $14 \%$ of lymphadenopathies, with intermediate and high-grade types predominant comprising $38 \%$ and $33 \%$ of NHL respectively (Table 2). Hodgkin's disease (HD) constituted $10 \%$ of lymphadenopathies with mixed cellularity as the commonest form comprising 39\% (Table 3).

Metastases constituted the remaining malignancies representing $19 \%$ of palpably enlarged peripheral nodes. Breast cancer involvement of axillary nodes was the most frequent (38\%) cause of lymph node metastases, followed by involvement of cervical nodes by carcinomas of the nasopharynx, thyroid \& salivary glands. Eight lymph node biopsies were characterized by non-caseous granulomas, three of which had necrotic foci with neutrophils suggestive of lymphogranuloma venereum or cat-scratch disease. The remaining five were mostly granulomas without caseation or other specific features. Other lesions included Kaposi sarcoma, chronic inflammatory fibrosis, acute lymphadenitis and nodes without significant pathology.

Cervical, axillary and inguinal were the most frequently biopsied comprising $46 \%, 23 \%$ and $13 \%$ respectively Table 2 ).

Table 1: Histological diagnosis and age in 356 patients with lymph node biopsies

\begin{tabular}{|c|c|c|c|c|c|c|c|c|}
\hline Histological diagnosis & $\begin{array}{l}\text { Age } \\
\text { (years) }\end{array}$ & & & & & & & Total $(\%)$ \\
\hline & $\leq 10$ & $11-20$ & $21-30$ & $31-40$ & $41-50$ & $51-60$ & $>60$ & \\
\hline Tuberculosis & 27 & 29 & 28 & 16 & 2 & 3 & - & $105(29.5)$ \\
\hline Reactive hyperpalsia & 21 & 14 & 10 & 10 & 7 & 3 & 3 & $68(19.1)$ \\
\hline Metastases & - & - & 9 & 14 & 26 & 11 & 8 & $68(19.1)$ \\
\hline Non-Hodgkin lymphoma & 12 & 8 & 6 & 6 & 7 & 6 & 3 & $48(13.5)$ \\
\hline Hodgkin's lymphoma & 6 & 8 & 9 & 2 & 5 & 6 & - & $36(10.1)$ \\
\hline Non-caseous granulomas & 1 & 3 & 3 & - & 1 & 1 & - & $8(2.2)$ \\
\hline Others & 5 & 3 & 4 & 4 & 5 & 2 & 1 & $23(6.7)$ \\
\hline Total & 72 & 64 & 68 & 51 & 53 & 32 & 15 & $356(100)$ \\
\hline
\end{tabular}


Table 2: Site of lymph node biopsies in 356 patients

\begin{tabular}{llllll}
\hline Diagnosis & Cervical & Axillary & Inguinal & Others & Total (\%) \\
\hline Tuberculosis & 61 & 22 & 3 & 19 & $105(29.5)$ \\
Metastases & 20 & 26 & 12 & 10 & $68(19.1)$ \\
Reactive hyperplasia & 21 & 11 & 16 & 20 & $68(19.1)$ \\
Non-Hodgkin lymphoma & 27 & 11 & 3 & 7 & $48(13.5)$ \\
Hodgkin lymphoma & 25 & 7 & 2 & 2 & $36(10.1)$ \\
Non-caseous granulomas & 3 & 2 & 2 & 1 & $8(2.2)$ \\
Others & 7 & 4 & 7 & 6 & $23(6.7)$ \\
\hline Total $(\%)$ & $163(46)$ & $83(23)$ & $45(13)$ & $65(18)$ & $356(100)$ \\
\hline
\end{tabular}

Table 3: Nodal lymphomas in 84 patients

\begin{tabular}{ll}
\hline Histological type & No. $(\%)$ \\
\hline Non-Hodgkin's & $14(29)$ \\
Low grade & $18(38)$ \\
Intermediate grade & $16(33)$ \\
High grade & $48(100)$ \\
$\quad$ Total & \\
Hodgkin's & $4(11)$ \\
$\quad$ Lymphocyte predominant & $5(14)$ \\
Lymphocyte rich & $11(30)$ \\
Nodular sclerosing & $14(39)$ \\
Mixed cellularity & $2(6)$ \\
Lymphocyte depleted & 36 \\
Total & \\
\hline
\end{tabular}

\section{Discussion}

As in virtually all other lymph node studies within and outside Nigeria, ${ }^{2-9}$ cervical nodes were by far the most frequently biopsied constituting $46 \%$ of nodal biopsies in this review. This was followed by axillary and inguinal biopsies, which comprised $23 \%$ and $13 \%$ respectively. The preponderance of cervical lymphadenopathy is a reflection of the fact that these nodes drain the upper aero-digestive tract through which most foreign antigens enter the body via inhalation or ingestion. Benign lesions were more preponderant comprising $57 \%$ of peripheral node enlargement, which is also consistent with all other studies. ${ }^{2-9}$

Cervical lymph node enlargement was most frequently due to tuberculosis that is also the commonest cause of all lymphadenopathy in this series accounting for $29.5 \%$. This is comparable to other Nigerian centres - $26 \%$ in Ibadan, ${ }^{12} 31.4 \%$ in Ilorin, ${ }^{5} 33 \%$ in $\mathrm{Jos}^{6}$ and $33 \%$ in Maiduguri ${ }^{7}$ but much lower than $47.8 \%$ in Ethiopia ${ }^{8}$ and $52 \%$ in Zambia. 9 The higher rates of tuberculous lymphadenitis in some African countries like Zambia is due to their higher HIV infection rates, tuberculosis being an AIDS-defining illness. ${ }^{9,10}$ In the last two decades, HIV/AIDS has also been responsible for the resurgence of tuberculosis in the Western world. ${ }^{13}$ Prior to the HIV pandemic, tuberculosis was declining due to improved living standards. ${ }^{13}$ Most $(80 \%)$ of our tuberculous lymphadenitis were diagnosed within the first three decades of life, which is consistent with the fact that primary $\mathrm{TB}$, the commonest type in childhood and adolescence chiefly involves lymph nodes. ${ }^{14,15}$

Collectively, lymphomas were the commonest malignancies and second most prevalent cause of palpably enlarged peripheral nodes accounting for $23.6 \%$, which is similar to $23.8 \%$ in Ife, ${ }^{15} 28.2 \%$ in Ilorin ${ }^{5}$ and $28.8 \%$ in $\mathrm{Jos}^{6}$ but higher than $19.1 \%$ in Maiduguri. ${ }^{7}$ Among the lymphomas, non-Hodgkin lymphomas (NHL) were more common comprising $13.5 \%$ of histologically diagnosed lymphadenopathies while Hodgkin's disease constituted just $10 \%$. With the exception of Maiduguri, ${ }^{7}$ most other Nigerian studies also document a preponderance of NHL over Hodgkin's. ${ }^{5,}{ }^{18-20}$ In the western world non-Hodgkin lymphoma (NHL) is reported to be three to four times more common than Hodgkin's and the incidence is rising while that of Hodgkin's is falling. ${ }^{23-25}$ The much higher proportion of NHL in the Western world than here in Africa, may be partly explained by racial and genetic factors as comparative studies in the United States document higher incidence among Whites than Blacks particularly for low grade follicular lymphomas. ${ }^{23-25}$ Intermediate and low grade lymphomas accounted for over $80 \%$ of NHL in the United States, ${ }^{23}, 25$ whereas high and intermediate grades were predominant in this review comprising $72 \%$. Mixed cellularity was the commonest form of Hodgkin's in this series as in most other reports ${ }^{18-20}$ from Nigeria.

Metastases comprised the remaining nodal malignancies constituting $19.1 \%$ of peripheral lymphadenopathies in Kano. Again, this is similar to reports from other parts of Nigeria ${ }^{5,7,14}$ but significantly higher than in Zimbabwe and Ethiopia. ${ }^{8}$,

${ }^{15}$ In the United States metastases comprised $29 \%$ of peripheral nodal enlargement, second only to reactive hyperplasia. ${ }^{2}$ Breast cancer involvement of axillary node was the commonest form of nodal metastases comprising $38 \%$ in this series. This reflected the growing scourge of breast malignancy, which globally is now the commonest female cancer. ${ }^{21}$

Reactive hyperplasia constituted nearly one-fifth (19.1\%) of enlarged peripheral nodes in this study, which is comparable to $22 \%$ in Maiduguri ${ }^{7}$ and $26 \%$ in Ethiopia ${ }^{8}$ but lower than $29 \%$ in Ife ${ }^{16}$ and $33 \%$ in Zimbabwe. ${ }^{14}$

In the United States, non-specific reactive hyperplasia is the premier cause of lymphadenopathy 
comprising nearly half of all cases. ${ }^{2,4}$ The relative absence of tuberculosis and earlier diagnosis of malignancies before the onset of nodal metastases may explain the prominence of reactive hyperplasia in the Western world.

Several cases of granulomas lacking caseation or other specific features were seen in this review. It is possible that some of these were early tuberculosis before the development of caseous necrosis, although they were negative for acid-fast bacilli (AFB). Histological demonstration of AFB by Ziehl-Neelsen stain in tuberculosis is notorious for its poor sensitivity. ${ }^{13}$ A study in Singapore demonstrated AFB in only $13.4 \%{ }^{26}$ of tuberculosis, while in Ibadan AFB was demonstrated in just over one quarter $(27 \%)$ of cases. ${ }^{12}$ This underscores the need for more sensitive techniques like fluorescence auramine staining, immunofluorescence and nucleic acid hybridization, which are presently unavailable in our laboratory. Sarcoidosis is also a differential diagnosis for these non-caseous granulomas but is uncommon in Africa although some reports indicate the contrary. ${ }^{27}$ Unfortunately the absence of confirmatory Kveim test in our centre makes it impossible to confirm or refute these claims. Granulomatous lesions of unknown significance (GLUS), a newly designated entity is a differential for these non-caseous granulomas. ${ }^{28}$

This study was carried out using routine histochemical stains ( haematoxylin and eosin and a few special stains). These are inadequate for a modern histopathology laboratory in a referral tertiary health institution, particularly as histo-diagnostic errors occur more frequently in lymph node biopsies than in other organs or tissues. ${ }^{29}$ Immunohistochemistry and cytogenetics will go a long way to improve the diagnostic accuracy of lymphoproliferative disorders and infectious diseases like tuberculosis. Proper histological classification of lymphoproliferative disorders requires molecular diagnostic techniques like immunohistochemistry and cytogenetics. It is important that these facilities are provided in Nigerian tertiary hospitals.

\section{References}

1. Rosai J. Lymph nodes. In: Ackerman's surgical pathology. Mosby, St. Louis, 1996; 1662-1670

2. Lee YT, Terry R, Luke RJ. Biopsy of peripheral lymph node. Am Surg 1982; 48:536-539

3. Ferrer R. Lymphadenopathy: differential diagnosis and evaluation. Am Fam Physician 1998; 58: 1313-1320

4. Henry PH, Longo DL. Enlargement of lymph node and spleen. In: Harrison's principles of internal medicine. McGraw-Hill, New York, 1998;345-347

5. Adeniji KA, Anjorin AS. Peripheral lymphadenopathy in Nigeria. Afr J Med med Sci 2000; 29:233-237

6. Obafunwa JO, Olomu IN, Onyia NJ. Primary peripheral lymphadenopathy in Jos, Nigeria. West Afr J Med 1992; 11:25- 28
7. Pindiga UH, Dogo D, Yawe T. Histopathology of primary peripheral lymphadenopathy in northeastern Nigeria. Nigerian Journal of Surgical Research 1999; 1: 68-71

8. Getachew A, Demissie M, Gemechu T. Pattern of histopathological diagnosis of lymph node biopsies in a teaching hospital in Addis Ababa 1981-90. Ethiopian Medical Journal 1999; 37: 121-127

9. Bem C, Patil PS, Bharucha H, Namaambo K, Luo $\mathrm{N}$. Importance of HIV associated lymphadenopathy and tuberculous lymphadenitis in patients undergoing lymph node biopsy in Zambia. Br J Surg 1996; 83:75-78

10. Cotran RS, Kumar V, Collins T. Acquired immune deficiency syndrome. In: Robbin's pathologic basis of disease. Saunders, Philadelphia, 1999;247-250

11. Non-Hodgkin lymphoma pathologic classification project: National Cancer Institute sponsored study of classifications of nonHodgkin's lymphoma. Summary and description of a working formulation for clinical usage. Cancer 1982; 49:2112-2135

12. Thomas JO, Ladipo JK, Yawe T. Histopathology of lymphadenopathy in a tropical country. East Afr Med J 1995; 12:703-705

13. Cotran RS, Kumar V, Collins T. Tuberculosis in: Robbin's pathologic basis of disease. Saunders, Philadelphia, 1999;349- 351

14. Edington GM, Gilles HM. Tuberculosis. In: Pathology in the tropics. Arnold, London, 1979; 393-395

15. Udani PM, Maddocks I. Tuberculosis. In: Jellife DB (ed). Diseases of children in subtropics and tropics. Arnold, London, 1981;301-312

16. Oluwole SF, Odesanmi WO, Kalidasa AM. Peripheral lymphadenopathy in Nigeria. Acta Trop 1985; 42:87-96

17. Sibanda EN, Stanczuk G. Lymph node pathology in Zimbabwe: a review of 2194 specimens. Q J Med 1994;86:811-817

18. Pindiga HU, Ahmed SG. Histological types of nodal lymphoma in northeastern Nigeria. Sahel Medical Journal (Nigeria) 2002; 5:43-46

19. Adedeji MO. Malignant lymphoma in Benin City, Nigeria. East Afr Med J 1989; 66:134-140

20. Obafunwa JO, Akinsete I. Malignant lymphoma in Jos, Nigeria: a ten-year study. Centr Afr J Med 1992; 38:17-25

21. Berg JW, Hutter PV. Breast cancer. Cancer 1995;75(suppl):257-269

22. Bunch C, Gatter KC. The lymphomas. In: Oxford textbook of medicine. Oxford Medical Publishers, Oxford, 1996;3568 Anderson JR, Armitage JO, Weisenburger DD. Epidemiology of non-Hodgkin's lymphoma: distribution of the major subtypes by geographic locations. Ann Oncol 1998; 9:717-720

23. Hartge P, Devessa SS, Fraumeni JF. Hodgkin's and non-Hodgkin's lymphoma. Cancer Surv 1994; 19-20:423-433

24. Croves FD, Linet MS, Travis LB, Devessa SS. 
Cancer survey series; non-Hodgkin's lymphoma incidence by histological type in USA from 19781995. J Natl Cancer Inst 2000; 92:1240-1251

25. Chee YC. Tuberculous lymphadenitis in Singapore. Ann Acad Med Singapore 1982; 11: 587-592

26. Awotedu AA, George AO, Oluboyo PO, et al. Sarcoidosis in Africans: 12 cases from Nigeria.
Trans R Soc Trop Med Hyg 1987; 81:1027-1029

27. Brincker H. Granulomatous lesions of unknown significance in biopsies from lymph nodes and other tissues. Sarcoidosis 1990; 7:28-30

28. Bunch C, Gatter KC. Lymph node biopsy histopathology. In: Oxford textbook of medicine. Oxford Medical Publishers, Oxford, 1996;3563 